\title{
Declining Voter Turnout in Comparative Perspective: A Result of Converging Party Profiles?
}

\section{Miki Caul Kittilson}

Voter participation has declined in 16 of 18 established industrial democracies between 1950 and 1998, while national electoral institutions have remained fairly constant. At the same time, analysis of Left-Right party profiles over the same period reveals that the majority of industrial democracies have witnessed a drift toward centrist party profiles. Do increasingly similar party profiles lower voters' sense of stake in elections, thereby contributing to declining turnout? Multivariate analysis of a pooled cross-section of elections from 1950 and 1998 suggests that converging party profiles have little impact, while unionization levels remain the strongest indicators of relative change in turnout levels.

\section{Introduction}

Research may pay less attention to falling levels of voter turnout if they are the result of a high degree of political satisfaction, as some suggest. However, if declining turnout is a consequence of fraying links between citizens, parties, and government, or a decreasing sense of political efficacy among citizens, then it challenges the very foundations of representative democracy. Fewer votes cast means less citizen input, and less citizen influence over policy outcomes.

Past cross-national research established that high levels of education and socioeconomic status are strong determinants of electoral participation at the individual level (Almond and Verba 1963, Verba and Nie 1972). Yet this is puzzling at the aggregate level: while education and incomes have steadily increased in industrialized democracies over the past fifty years, levels of voter turnout in national elections have continued to decline. Although one might expect rising education and income levels to lead to greater participation, these demographic changes may also counteract the individual-level influences. The growth of the service sector and rise of the new middle class in industrialized nations has re-shaped the traditional class

MIKI CAUL KITTILSON is Assistant Professor in the Department of Political Science at the University of Texas San Antonio. Her research interests include comparative political participation, parties, and women in politics. Her research has appeared in journals such as Comparative Political Studies, Journal of Politics, and Party Politics. The author would like to thank the Comparative Manifestos Project (Ian Budge, Hans-Dieter Klingemann, Andrea Volkens, Judith Bara, Eric Tannenbaum) for generously sharing their data, Mark Gray for sharing updated turnout and labor union data, and Jonathan Bernstein and Rachel Epstein for their suggestions.

The American Review of Politics, Vol. 23, Winter, 2002: 355-377

(C)2002 The American Review of Politics 
structure. Previously well-defined political cleavages have become more difficult to discern and even more difficult to organize. The union-labor party link grew increasingly weaker in almost all industrial democracies, relative to its height in the 1960s. ${ }^{1}$ The decline of loyal bases of voters has made it more difficult for parties to structure voting choices in coherent ways. The role of political parties in the electorate changed substantially in post-industrial democracies (Dalton and Wattenberg 2000). As a consequence, citizens may be less connected to politics in contemporary democratic societies.

Studies of electoral participation are often based upon a cost/benefit analysis. On the one hand, lowering the costs of voting through electoral institutions such as automatic registration, weekend and holiday voting, and eliminating 'wasted votes' with more proportional vote-to-seat translations, is expected to encourage voting (Powell 1986; Jackman 1987, Jackman and Miller 1995). On the other hand, the political benefits of voting for one's preferred party, in part, stem from the assumption that parties offer clear distinctions to voters, and more specifically clear benefits to groups of voters. By extension, if political parties look similar, then voting yields little benefit.

This research is based upon the premise that voters are more likely to turn out at the polls when casting their vote means making a meaningful choice. In representative democracy, parties link citizens to government through the policy alternatives they offer voters, which are often organized though long-standing ties to groups in society. Previous research has found that union and leftist party strength are important determinants of turnoutprimarily in terms of mobilization efforts (Gray and Caul 2000; Radcliff and Davis 2000). The unique perspective of this research is that organizations and parties do more than get-out-the-vote; they also connect citizens to the democratic process in structured ways. Party programs that aggregate policies and issues in clear and coherent ways provide cues to voters. Increasingly similar partisan profiles may have reduced citizens' sense of stake in political outcomes, making them less inclined to cast their vote. This hypothesis is tested across 18 continuously democratic, industrial democracies from 1950 to 1998.

In reviewing the voter turnout literature, Franklin $(2002,164)$ argues that patterns in electoral participation reflect "the coming and passing of a peak of interest generated by electoral decisions relating to [the long-standing conflict between labor and capital]. So elections in recent years may see lower turnout for the simple reason that these elections decide issues of lesser importance than elections did in the late 1950s; but until we have some way to measure the substantive importance of electoral contests in terms that are comparable cross-nationally it will not be possible to be definite about this." 
Perhaps issues have not become less important, but rather in an era of more fluid connections between parties and citizens, and more professional, image-conscious campaigns, parties have simply presented more ambiguous alternatives, and as a consequence voters' perceptions about the salience of elections have changed. This research examines the link between party profiles and voter turnout. First, patterns in voter turnout levels and party profiles are examined within each of the 18 nations over time. Then, the relationship between the two is examined in a multivariate model, controlling for the explanations offered in previous research.

\section{Establishing Turnout Decline}

Comparison of turnout levels from 1950 to 1998, as displayed in Table 1 , shows that citizen participation in elections is decreasing across established industrial democracies. The first two columns of Table 1 display the percentage point difference in voter turnout from the average of any nation's first two elections in the 1950s to the average of that nation's two most recent elections and the difference between the nation's highest and lowest turnout elections since $19500^{2}$ Relative to their 1950 s levels, voter turnout has declined in 16 of the 18 post-industrial democracies in this study. Over one-third of the nations in this study experienced turnout variation larger than 15 percentage points in parliamentary national elections. Even Australia with its compulsory voting law experienced a nine percentage point differential between its highest and lowest levels of turnout since 1950. Only in Denmark and Sweden has turnout increased from its levels in the 1950s. Yet if we had chosen a later time point from which to start our calculations, for example 1960, then Sweden and Denmark would also show a slight decline.

This pattern is supported by recent research. In a study of turnout in 24 advanced industrial democracies from 1980 to 1998, Ghobarah (1998) found a 2.5 percentage point decline from 1980 to 1990 and another 4.5 percentage point decline from 1990 to 1998 using a pooled average of the levels of voter turnout across his sample. ${ }^{3}$

In this research turnout is measured as the percentage of valid votes cast by the voting age population in any given election. This follows the work of Powell (1986) and the IDEA (1997) global participation report. Utilizing the voting age population ensures that all who are eligible are counted. The disadvantage in utilizing voting age population is that felons and noncitizens are included. However, as Wattenberg (2002) notes, this percentage of the population may be more consistent over time than registration lists, which could enter non-systematic variation into the analysis.

Scholars of comparative participation have debated the importance of a decline in turnout. Both Topf (1995) and Franklin (2002) view turnout rates 
Table 1. Percentage Point Changes and Variation in Turnout

\begin{tabular}{|c|c|c|}
\hline Nation (N) & $\begin{array}{l}\text { Change in Turnout } \\
\text { Since } 1950 \mathrm{~s}\end{array}$ & $\begin{array}{c}\text { Highest - Lowest } \\
\text { Turnout 1950-97 }\end{array}$ \\
\hline Australia $(20)^{\mathrm{c}}$ & -0.7 & 9.0 \\
\hline Austria (14) & -11.9 & 14.4 \\
\hline Belgium $(15)^{\mathrm{c}}$ & -4.6 & 10.4 \\
\hline Canada (15) & -3.3 & 15.7 \\
\hline Denmark (19) & +2.9 & 13.0 \\
\hline Finland (13) & -5.7 & 14.0 \\
\hline France (13) & -13.3 & 16.7 \\
\hline Germany (13) & -9.1 & 17.0 \\
\hline Ireland (13) & -4.2 & 15.5 \\
\hline Italy $(12)^{\mathrm{c}}$ & -7.5 & 11.3 \\
\hline Japan (17) & -10.4 & 14.8 \\
\hline Netherlands $(13)^{\mathrm{c}}$ & -8.8 & 14.6 \\
\hline New Zealand (16) & -17.6 & 23.1 \\
\hline Norway (12) & -2.2 & 10.8 \\
\hline Sweden (16) & +4.3 & 13.0 \\
\hline Switzerland (12) & -23.8 & 27.0 \\
\hline United Kingdom (14) & -6.3 & 12.3 \\
\hline United States (24) & -9.5 & 11.1 \\
\hline \multicolumn{3}{|c|}{$\begin{array}{l}\text { Data compiled from Gray and Caul (2000) and sources listed in Appendix. Legislative elections only } \\
\text { except for U.S. entries which are based on presidency. }{ }^{\circ} \text { Use of compulsory voting laws. Change } \\
\text { since } 1950 \text { s represents the percentage point difference of the average of the two most recent } \\
\text { elections from the average of the first two post- } 1950 \text { elections. }\end{array}$} \\
\hline
\end{tabular}

as cyclical over time, and argue that because turnout was at a historical high point in the 1960s, it not surprising that it has declined in recent decades. Both Topf and Franklin imply a process of 'regression toward the mean.' However in an era in post-industrial societies where literacy, education, urbanization, and political information, and even high levels of political interest are widespread, it is logical to expect the high rates of turnout to continue, if not rise further. High voter turnout rates may be one symbol of the vitality of democracy, and a decline may signal decreasing legitimacy in the democratic process.

\section{Explanations for Turnout Decline}

Comparative voter turnout research is distinguished by seminal studies that highlight the importance of institutional characteristics in explaining cross-sectional variation among countries (Powell 1986; Jackman 1987; Jackman and Miller 1995). Certainly compulsory voting laws yield higher 
turnout. Jackman finds that proportionality, unicameralism, and what he calls "nationally competitive districts" have had a moderate positive effect on voter turnout. Jackman reasons that proportional systems make the voter feel more efficacious because this type of votes-seats allocation increases the likelihood that the individual vote impacts a party's share of seats in parliament and perhaps may even determine the final selection of a government. Jackman also theorizes that bicamerialism leads to a less decisive role for the lower house in the legislative process. The reduced saliency of legislative elections at the lower level of parliament decreases voters' perception that their vote can make a difference in policy outcomes.

Taken together, research shows that electoral rules influence comparative levels of turnout. Yet while turnout has systematically declined during the post-World War II era, electoral institutions have remained fairly constant within advanced industrial democracies. There have been some important systematic and noninstitutional changes that have yet to be identified that may explain the decline in turnout within advanced industrial democracies.

In addition to electoral institutions, the nature of the party system has considerable influence on the aggregate level of voter turnout and on dynamics between elections. Specifically, one might expect that where there is a greater number of party alternatives on the ballot, it is more likely that there is a party close to individual voters' preferences. Thus, a higher number of parties may draw more voters to the polls. Dittrich and Norby Johansen (1983) conclude that large changes in fractionalization of the party system, both positive and negative, encourage turnout while modest changes discourage turnout. It may be that activity in the party system attracts voters' attention and draws them to cast a vote or that during realignments citizens are being mobilized into a new party structure, thereby increasing the aggregate levels of turnout.

Importantly, the 'salience of elections' in terms of party competition should also affect turnout levels (Jackman 1987; Jackman and Miller 1995). Franklin (2002) argues that both cross-national and cross-temporal variation in electoral participation are largely a functions of the election context. When voters perceive elections as critical, and their votes decisive, they will turn out at the polls. Specifically, Franklin's systematic and comprehensive cross-national analysis finds closeness of the race, and the likelihood that one party will win control of the legislature encourage voting. Thus, in elections where the major parties are in heated competition, voters may be stimulated to vote.

It is often argued that voters' unhappiness with high levels of inflation or unemployment may make them more likely to register their discontent at the polls. The findings of Lewis-Beck and Lockerbie (1989) suggest that the 
perception that the economy will do well in the year to come heightens the likelihood that respondents will vote. Radcliff's $(1992 ; 1996)$ research reveals that economic growth during the year before an election compels voters to go to the polls in greater numbers. In short, it is important to control for economic conditions in election-to-election variation.

Recent research on comparative voter turnout focuses on explaining decline, and emphasizes the importance of group-based mobilization in turning out the vote. Organizations are often responsible for contacting, educating, and reminding their members of the importance of their votes on election day. Rosenstone and Hansen (1993) highlight the importance of mobilization efforts in the American context, noting: "People participate in electoral politics because someone encourages or inspires them to take part" (161). Specifically, labor parties and unions have traditionally encouraged working class voters to go to the polls. ${ }^{4}$ Burnham (1965) was one of the first to point toward the connection between a strong Leftist, or labor-based, party and the mobilization of periphery voters. Yet since the 1960s, both the level of unionization (see Griffin et al. 1990) and the vote share of labor parties have declined in many democracies. ${ }^{5}$ Gray and Caul (2000) find that declining levels of voter turnout are to a large extent the products of declining levels of union density and the diminishing success and effectiveness of traditional labor-affiliated parties in industrial democracies.

In a similar fashion Radcliff and Davis (2000) examine turnout levels in industrial democracies both cross-sectionally and over time. They find that union density is an important determinant of turnout, and emphasize the role of unions both as a mobilization force, and as a 'voice' for the working class. Their results reveal that part of the union effect "occurs indirectly through labor's ability to move the ideological position of parties appealing to lower- and middle-status citizens farther to the left" (132).

The decline in party mobilization does not appear to be limited to the Left. Parties across the ideological spectrum in many nations are losing their 'partisans'- both cognitively and in an active sense (Dalton and Wattenberg 2000). Russell Dalton (2000) finds that party identification has gradually weakened in most industrial democracies. In addition, affective support for political parties has declined as well. Similarly, Scarrow (2000) finds that party membership percentages have fallen. As a consequence, Wattenberg (2000) theorizes that parties are no longer mobilizing voters to the extent they once did.

Even more important than mobilization efforts, parties and unions encourage turnout because they may also provide a value to a vote. In his seminal study Powell (1986) was the first to emphasize the importance of party-demographic group linkage, reasoning that cognitive "links" between economic or religious groups and parties encourage citizens to vote. Where 
party-group differentials in support are more pronounced (measured by the class voting index), voter turnout is highest. Yet Powell's analysis is static, so he is unable to estimate the impact of party linkages over time.

Citizens are organized through groups, which connect them to the democratic process through their ties to parties. Further, the benefits of electoral participation are most often structured in terms of groups. Uhlaner $(1989,391)$ concludes that group identifications can make it more rational for particular segments of the electorate to show up at the polls, even when the cost-benefit incentive structure clearly predicts that they should not. Clear, distinct party profiles are therefore important to structuring voters' choices at the ballot box. By emphasizing consistent themes targeting fixed groups of supporters, parties provide cues to voters. The basic tenets of partisan theory are based on the idea that parties pursue policies that benefit their core constituencies (Hibbs 1977). For example, the working class base of leftist parties demands low unemployment, while the business group supporters of major rightist parties demand low inflation, even at the risk of higher unemployment. These party-group ties were once so predictable that the seminal study by Lipset and Rokkan (1967) labeled party system alignments 'frozen' in industrial democracies.

As a consequence of the socio-economic transformations of the postWar era, the relationships between citizens and fixed social groupings have weakened. Parties today certainly operate in a different electoral environment (Dalton, Flanagan, and Beck 1984; Crewe and Denver 1985). In many cases in established industrialized democracies, the relationship between parties and interest groups has declined, especially the traditional links between trade unions and socialist parties since the 1970s (Taylor 1993; Pierre and Widfeldt 1992; Selle 1997; Thomas et al. 2001). This pattern of attenuating links is especially pronounced in northern Europe. Poguntke's (1998) research on Western European parties finds that links to external, ancillary organizations are waning, while links with internal interests groups are on the rise. These changes come as an increasing number of countries are granting subsidies to political parties, thus reducing their reliance on donations from organized interests (Thomas et al. 2001).

\section{Party Convergence?}

In an increasingly fluid environment, it may be increasingly difficult for parties to maintain distinct policy profiles. Kirchheimer (1966) predicted that former mass parties would become 'catch-all parties' in an effort to maximize their share of the votes. As the traditional bonds that once structured party competition diminish, Kirchheimer theorized that parties would integrate more voters drawn from increasingly diverse segments of society. 
Even in multiparty systems, there may be pressure to converge toward the center. Mair (1995) theorizes that as leading Left and Right parties move toward the center of the spectrum, the range of coalition alternatives increases, and individual parties find it more difficult to maintain a separate identity.

A series of studies suggest major parties have moved toward the center of the traditional Left-Right ideological spectrum. Caul and Gray (2002) find that political parties across advanced industrial democracies increasingly find it difficult to maintain distinct identities. In most countries there has been a general drift towards the center of the Left-Right ideological spectrum. Likewise, Klingemann et al. (1994) find a general convergence of major parties through 1987. Similarly, Thomas $(1975 ; 1979)$ finds a pattern of convergence in ten Western European party systems from 1950 to 1970. In addition, basing their studies on expert judgments of party positions in 1982 and 1993, in separate studies Mair (1995) and Knutsen (1998) find the distance between major Left and Right parties has narrowed.

This process of convergence can be seen in elections in many party systems. For example, several analysts of British electoral politics pointed to the emergence of a collectivist consensus between Labor and the Conservatives that lasted until the Thatcher era (Norton 1994; Beer 1969), and then again under Major and Blair (Sanders 1998; King et al. 1998). Similarly, the neo-liberal convergence in the party platforms of the major Left and Right parties in New Zealand in the late 1970s allegedly planted the seeds of public discontent that culminated in the 1993 electoral system reform (Vowles et al. 1995). Likewise, the space between the established parties of Finland has steadily shrunk since the 1980s, and the major left and right parties have even governed as a coalition (Pesonen 1999).

If parties offer increasingly similar policy profiles, they may no longer simplify the vote choice. By tracing the relative distance in how parties present their profiles to voters, it is possible to examine whether there is a pattern of movement toward the center. Updating the research of Caul and Gray (2000), party profiles are examined from 1950 to 1998. Party platforms, or manifestos, detail the promises parties make before an election, and depict the images that parties communicate to voters.

The best available data source that allows analysis of change in how parties present themselves to the public at election time in broad ideological terms over the greatest amount of time and number of countries comes from the Comparative Manifestos Project. Their systematic analysis of party platforms across 18 democracies provides the basis for standardized comparison of party profiles from 1945 to 1998 (Budge et al. 1987; Klingemann et al. 1994). The project coded the content of party election programs in terms of attention to 54 separate themes. ${ }^{6}$ Following Klingemann et al. $(1994,40)$ an 
index of the percentage of each party's platform dedicated to issues with a leftist emphasis and the percentage with a rightist emphasis was created, and then the difference between the Left and Right indices was calculated to create a summary ideological score for each party in a given election year. For example, the major leftist party may change its emphasis on an antimilitary stance, or the regulation of capitalism, or call for nationalization. A rightist party may emphasize free enterprise, anti-protectionism, or antiwelfare themes (see Appendix for a complete list of categories).

The ideological distance between the major Left and Right party in each nation from the 1950 s to the 1990 s is presented in Table 2. ${ }^{7}$ The first and second columns present the average distance between these leading parties for the first two elections in the 1950s, and the last two elections in the 1990s, respectively. The third column presents the percentage point difference between these two time points. The distance between Left and Right parties decreased in 14 of 18 nations over time. Both the average decrease and increase is nearly 17 percentage points. The fourth column displays the

Table 2. Ideological Distance Between Major Left and Right Party, 1950-1990s

\begin{tabular}{|c|c|c|c|c|}
\hline Nation (N) & $\begin{array}{c}\text { 1950s } \\
\text { Average }\end{array}$ & $\begin{array}{c}\text { 1990s } \\
\text { Average }\end{array}$ & Change & $\begin{array}{l}\text { Per Annum } \\
\text { Change }\end{array}$ \\
\hline Australia (20) & 51.5 & 16.8 & -34.7 & $-.50 *$ \\
\hline Austria (14) & 56.4 & 27.5 & -28.9 & $-.68 * *$ \\
\hline Belgium (15) & 25.2 & 14.2 & -11.3 & -.04 \\
\hline Canada (15) & 39.5 & 32.5 & -7.0 & .06 \\
\hline Denmark (19) & 25.7 & 61.0 & +35.3 & $.47 *$ \\
\hline Finland (13) & 41.8 & 17.0 & -24.8 & -.51 \\
\hline France (13) & 26.3 & 17.6 & -8.7 & -.40 \\
\hline Germany (13) & 46.0 & 35.6 & -10.4 & .24 \\
\hline Ireland (13) & 33.1 & 13.5 & -19.6 & $-.89 * *$ \\
\hline Italy (12) & 15.3 & 38.0 & +22.7 & .23 \\
\hline Japan (13) & 14.2 & 19.9 & +5.7 & .06 \\
\hline Netherlands (13) & 36.0 & 18.0 & -18.0 & $-.40 *$ \\
\hline New Zealand (16) & 52.2 & 17.7 & -34.5 & $-.56^{*}$ \\
\hline Norway (12) & 47.1 & 34.1 & -13.0 & -.33 \\
\hline Sweden (16) & 35.7 & 28.7 & -7.0 & -.38 \\
\hline Switzerland (12) & 55.6 & 50.2 & -5.4 & .10 \\
\hline United Kingdom (14) & 33.6 & 37.0 & +3.4 & .59 \\
\hline United States (12) & 26.3 & 16.8 & -9.5 & .09 \\
\hline
\end{tabular}


per annum change in the difference between the Left/Right ideological position of the two parties over the span of the data. Here the signs are negative in only 10 cases. In most cases change within national time series is not an even decline, but rather punctuated by spikes in both directions, eventually heading downward over the long-run. In short, these results both strengthen and update the findings of Caul and Gray (2000), Budge et al. (1987), and Klingemann et al. (1994).

The three majoritarian electoral systems - Canada, Australia, and New Zealand - are most likely to display convergence toward the median voter. In these nations the converging forces described by Downs presumably combine with the general centralizing tendencies that may affect all party systems. ${ }^{8}$ Yet importantly, ideological convergence is also visible in Germany and Austria with mixed electoral systems, as well as in proportional representation systems such as the Netherlands, Norway, Belgium, Finland, and Italy.

The American political party system is an exception to the general convergence pattern. As others have shown, the polarization between the Democratic and Republican parties increased into the 1980s (King 1997). Although the U.S. ended up in the 1990s with less polarization, the ideological gap at the end of the 1980s was nearly double that in the 1950s. In 1984 there is an unprecedented ideological polarization, corresponding with the 'Conservative Revolution' associated with Reagan's re-election campaign. After 1984, however, these data show that the polarization falls again, back to the small gap traditionally found in the U.S.

In a potential offset to the trend toward the convergence of established parties, New Politics parties may have entered the party system and maintained the broader ideological range in some party systems (Knutsen 1998; Wagschal 1998). Over this time span many of these democracies have witnessed the consolidation of new Green parties in the party system (MuellerRommel 1989) and more recently, New Right parties. So, even if the major Left and Right parties have generally converged, the ideological diversity of entire party systems may have followed a different course - by new parties moving into the space vacated by the major parties.

In order to test for this possibility, the Left/Right ideological diversity of the entire party system was computed using the party manifesto data. Each political party in the manifesto project was given a summary Left/ Right score, and this ideological score was weighted by the party's share of the votes at each election. Then, the standard deviation of weighted party scores was computed for each election. This weighting makes each party's contribution to the diversity score in proportion to the voters it represents in the party system. Thus larger parties make a greater contribution to the measure of ideological diversity than do smaller extremist parties, so that the 
Table 3. Change in Ideological Dispersion Across Party Systems, 1950-1990s

\begin{tabular}{|c|c|c|c|c|}
\hline Nation $(\mathrm{N})$ & $\begin{array}{c}\text { 1950s } \\
\text { Average }\end{array}$ & $\begin{array}{c}\text { 1990s } \\
\text { Average }\end{array}$ & Change & $\begin{array}{l}\text { Per Annum } \\
\text { Change }\end{array}$ \\
\hline Australia (20) & 32.0 & 10.0 & -22.0 & $-.33 * *$ \\
\hline Austria (14) & 26.5 & 19.4 & -7.1 & -.19 \\
\hline Belgium (15) & 17.6 & 6.7 & -10.9 & -.11 \\
\hline Canada (15) & 14.9 & 18.5 & +3.6 & $.16^{* *}$ \\
\hline Denmark (19) & 13.9 & 28.6 & +14.7 & $.23 *$ \\
\hline France (13) & 18.8 & 24.7 & +5.9 & .02 \\
\hline Finland (13) & 29.8 & 15.5 & -14.3 & -.20 \\
\hline Germany (13) & 22.0 & 20.1 & -1.9 & .12 \\
\hline Ireland (13) & 18.8 & 8.9 & -9.9 & $-.35^{*}$ \\
\hline Italy (12) & 10.1 & 22.2 & +12.1 & $.24 * *$ \\
\hline Japan (13) & 10.3 & 10.2 & -0.1 & -.08 \\
\hline Netherlands (13) & 19.0 & 10.8 & -8.2 & $-.20 * *$ \\
\hline New Zealand (16) & 25.7 & 13.0 & -12.7 & -.21 \\
\hline Norway (12) & 24.2 & 21.7 & -2.5 & -.06 \\
\hline Sweden (16) & 31.4 & 20.3 & -11.1 & $-.29 *$ \\
\hline Switzerland (12) & 24.6 & 23.2 & -1.3 & -.05 \\
\hline United Kingdom (14) & 16.2 & 19.6 & +3.4 & $.27 *$ \\
\hline United States (12) & 13.2 & 8.4 & -4.8 & .04 \\
\hline
\end{tabular}

diversity measure more accurately reflects the entire distribution of ideology in a party system.

Table 3 traces the changes in the ideological diversity of each party system over time. The first set of columns represent the average ideological diversity (standard deviation) for the party system in the first two elections of the 1950s and the last two elections of the 1990s, and the difference between the two time points. The results reveal that the dispersion across party systems decreased in 13 of our 18 nations over this time period. The average increase and decrease both hovered around eight percentage points. The fourth column presents the per annum change in the ideological diversity. Of the 18 countries for which we have data, ideological diversity decreases in 11 (five are statistically significant even though the number of cases is quite small). ${ }^{9}$

Australia, Austria, Belgium, Finland, Ireland, the Netherlands, New Zealand, and Sweden showed the sharpest evidence of convergence beginning in the 1970s. In other instances, such as Italy, it was clear that the 
entrance of new parties had increased the range of diversity in the system. Nevertheless, the general trend for most established democracies is for the major Left and Right parties, and for the party system as a whole, to display a pattern of ideological convergence over time. Further, national patterns are generally consistent whether one focuses on only the major parties or the party system as a whole. ${ }^{10}$

\section{Multivariate Analysis}

The primary goal of this research is to test the impact of shifting party profiles on changes in voter turnout levels over time. At the same time it is certainly important to create a multi-faceted set of explanations that incorporates previously hypothesized influences on turnout, as detailed above. To test these explanations for the variation in turnout, a dataset ${ }^{11}$ containing turnout levels and relevant national-level characteristics observation by observation was constructed for 240 elections. ${ }^{12}$

The sample size and resulting degrees of freedom allow for the legitimate use of ordinary least squares regression (OLS). However, there are risks associated with OLS estimates because they treat each observation as an independent event. In the stacked pooled data set used in this study, this is clearly not the case, as turnout in any given nation at any time is more than likely strongly related to the unique qualities of that nation within that specific frame of time. ${ }^{13}$ This problem could potentially lead to violations of OLS assumptions regarding the error terms. This is most likely to occur when one relies on untransformed data that measure the actual levels of variables across time (Table 4$){ }^{14}$

The variables were transformed into index measures that quantify change over time. This procedure rendered the time-series cross-sectional data stationary, thereby helping avoid the problems associated with correlated error terms. ${ }^{15}$ This procedure also allows measurement of change over time within nations rather than differences between nations. Following these requirements the dependent variable was operationalized at each observation, as the percentage point difference from the average level of turnout in the first two post-1950s elections in each nation and type of election (presidential or legislative).

\section{Changes in Turnout $_{i}=$ Turnout $_{i}$ B Turnout avg1950s}

By this method each observation of turnout is converted into a measure of change from a nation's 1950s levels. ${ }^{16}$ Through this process a great deal of the between-country variation in turnout is removed by standardizing every nation's series to the same baseline, allowing for models which explain long-term turnout decline within countries. ${ }^{17}$ 
Table 4. Unreported Model: National-Level Differences in Turnout (untransformed)

\begin{tabular}{|c|c|}
\hline Variables & $\begin{array}{l}\text { Differences Between Countries } \\
\text { (actual levels) }\end{array}$ \\
\hline Constant & $.8000 * * *$ \\
\hline $\begin{array}{l}\text { Party Profile Differences } \\
\text { Difference in Major Left and Right Party Profiles }\end{array}$ & .0001 \\
\hline $\begin{array}{l}\text { Group Mobilization } \\
\text { Change in Labor Party Vote Share } \\
\text { Change in Union Density }\end{array}$ & $\begin{array}{l}.0080 \\
.2290 * * *\end{array}$ \\
\hline $\begin{array}{l}\text { Party System } \\
\text { Change in Margin of Victory } \\
\text { Change in Number of Parties }\end{array}$ & $\begin{array}{r}-.0028 \\
.0009\end{array}$ \\
\hline $\begin{array}{l}\text { Demographic/Economic } \\
\text { Change in Inflation (CPI) } \\
\text { Change in Economic Growth (GDP) }\end{array}$ & $\begin{array}{r}-.0028 * * * \\
.0000 * * *\end{array}$ \\
\hline $\begin{array}{l}\text { Institutional } \\
\text { Electoral Competitiveness }_{\text {Compulsory Voting }^{\mathrm{a}}} \\
\text { Unicameralism }^{\mathrm{a}} \\
\text { Voting Holiday }^{\mathrm{a}} \\
\text { Presidential Election }^{\mathrm{a}}\end{array}$ & $\begin{array}{l}.0093 * * * \\
.0002 \\
.0018 \\
.0001 \\
-.1100 * * *\end{array}$ \\
\hline $\begin{array}{l}\text { Number of Cases } \\
\text { Adjusted } \mathrm{R}^{2}\end{array}$ & $\begin{array}{l}250 \\
.90\end{array}$ \\
\hline \multicolumn{2}{|c|}{$\begin{array}{l}{ }^{*} \mathrm{p}<.10 ;{ }^{*} \mathrm{p}<.05 ; * * * \mathrm{p}<.01 \text {. The dependent variable is the level of valid vote turnout of VAP. All } \\
\text { explanatory variables are based on their levels, not changes. Entries are unstandardized regression } \\
\text { coefficients. } \\
\text { a Dummy variable. National dummy variables for B1 nations (Austria is the excluded country) ex- } \\
\text { cluded from the table. Presidential election dummy is included to control for the panel structure of } \\
\text { the data. } \\
\text { Source: Data sources are listed in Appendix. }\end{array}$} \\
\hline
\end{tabular}

The same process was utilized to standardize and convert some of the independent variables. Measures of party profile differences, labor party vote shares, union density, margin of victory, and number of parties are converted to specific unit changes from the average of the first two 1950s elections for each nation and election type (see Appendix). With greater divergence from the baseline of any variable, it is logical to assume that there will be some equivalent magnitude of change in turnout. By contrast, the electoral institution variables should act as mediating forces, and as such these 
are measured as dummy or scale variables. For example, converging party profiles are likely to have less impact where voting is compulsory or where registration is automatic. These institutional variables were thus operationalized as dichotomous variables, except the "electoral competitiveness measure," which is a scale of the proportionality of the electoral rules.

Elections before 1945 could not be included because of the sweeping changes to the political and party systems brought about by World War II. Further, many of the nations in the sample did not have elections during the war period or were under different regimes. Elections between 1945 and 1950 are excluded to create a buffer zone of time in which many of the nations in the sample were rebuilding and reconstituting under new constitutions and electoral rules. Each nation's first two post-1950s elections were averaged to establish how voter turnout was generally operating in the immediate post-war era after reconstruction, thus allowing the longest uninterrupted series of elections possible.

\section{Results and Discussion}

The results of the multiple regression are displayed in Table $5{ }^{18}$ Interpreting the regression results in Table 5 is for the most part straightforward. A one-unit change in any of the independent variables is associated with a change in turnout relative to the level of turnout experienced in the first two post 1950s elections, which is equal to the magnitude of the unstandardized coefficient (all percentages, including turnout, were measured in decimal form).

The multivariate equation reveals that, contrary to expectations, change in the relative differences between the major Left and Right party profiles had virtually no impact on relative turnout rates. ${ }^{19}$ Instead, relative change in unionization levels exerts the strongest influence on voter turnout. ${ }^{20}$ The finding that falling unionization levels substantially impede voter turnout provides strong support for previous research (Gray and Caul 2000; Radcliff and Davis 2000). A complimentary measure of mobilization, change in leftist party strength relative to its 1950 s level, does not qualify as statistically significant in this analysis.

Again it is evident in this analysis that largely static institutional explanations offer little utility in explaining declining turnout. Even where electoral institutions, such as compulsory voting or the number of legislative chambers have been altered, their impact on turnout over time has been minimal. Although their impact on changing turnout is quite minimal, entering these variables into the equation as controls is certainly important in terms of theory. These institutions are mediating factors, and certainly should not be absent from any research on electoral participation. 
Table 5. Multivariate Explanation of Change in Turnout Decline

\begin{tabular}{lcc}
\hline Variables & Unstandardized B & Standard Error \\
\hline Constant & $.9800^{* * *}$ & .0310 \\
Party Profile Differences & & \\
Difference in Major Left & .0001 & .0000 \\
and Right Party Profiles & & \\
Group Mobilization & .1300 & .0950 \\
Change in Labor Party Vote Share & $.2430^{* * *}$ & .0690 \\
Change in Union Density & & \\
Party System & .0593 & .0810 \\
Change in Margin of Victory & $.0091^{*}$ & .0050 \\
Change in Number of Parties & & .0010 \\
Demographic/Economic & .0009 & .0020 \\
Change in Inflation (CPI) & $.0042^{* *}$ & \\
Change in Economic Growth (GDP) & & .0020 \\
Institutional & .0006 & .0290 \\
Electoral Competitiveness & .0118 & .0390 \\
Compulsory Votinga & .0540 & .0220 \\
Unicameralism & \\
Voting Holiday & .0205 & \\
Number of Cases & 230 & \\
Adjusted R & .646 & \\
*p $<.10 ; * *$ p $<.05 ; * * * p<.01$. & & \\
${ }^{a}$ Dummy variable. Table omits atheoretical country dummy variables. & \\
Source: Data compiled by authors from sources listed in appendix. & \\
\hline
\end{tabular}

In short, the broader theory that that centrist party politics may discourage voting is by and large not supported in this analysis. Instead, the effects of declining unionization and working class party strength appear to lower voter turnout through effects on mobilization, rather than through indirect effects on cognitive links to party policy differences. Yet it may be fruitful for future research to go beyond party platforms as a measure of a shift toward centrist party politics. Party platforms may be targeted toward the most loyal and active party supporters, rather than the mass electorate. Therefore these documents may send the most partisan, ideologically coherent of all the messages the party projects. Presumably the most ambiguous messages are directed toward the electorate at-large. Further, the aggregation of concerns that parties present through platforms may not reflect the image of parties in the average voter's mind. Few of the most dedicated party voters read and compare platforms. Indeed, party images are also conveyed 
to voters through debates, rallies, pamphlets, advertisements and media coverage. Yet these messages to voters are certainly difficult to measure on a cross-national, cross-temporal basis.

The theoretical underpinning of this research points toward a new agenda for comparative electoral behavior research. Rather than limiting its focus to lowering the 'costs' of participation-whether through automatic registration, weekend or holiday voting, it is also imperative to carefully assess changes in perceived 'benefits.' If research is to explain the processes behind declining turnout in a comprehensive manner, then further investigation of the flip-side of the cost-benefit analysis of electoral participation is a necessary addition. Yet investigating policy preference-based incentives for voting will undoubtedly be much more challenging than assessing the impact of institutional characteristics. Cross-national studies of voting behavior have largely been built upon individual-level theories and assumptions, and tested with aggregate-level data. Clearly comparative micro-level research would make an important contribution.

Because declining union strength has been linked to declining turnout largely through its mobilization effects, this suggests that voter abstention is increasingly concentrated among 'peripheral' voters. In other words, as Rosenstone and Hansen's (1993) research on the U.S. suggests, those citizens who are the most in need of the get-out-the-vote drives and incentives that these organizations traditionally provide, may be increasingly unlikely to cast their ballot. If declining turnout is not 'randomly distributed' in society, as Arend Lijphart (1998) suggests, then it may be a growing problem with fundamental consequences for the legitimacy of the democratic process.

\section{APPENDIX Variable Descriptions}

Voter Turnout (VAP): The percentage of voting-age population casting valid votes in national elections. Data are derived from Gray and Caul (2000), originally from Mackie and Rose (1991) and updated from IDEA Database (1997), Electoral Studies, and The European Journal of Political Research.

Labor Parties Vote Shares: A sum of the total vote shares in any given election going to parties who explicitly identify themselves as Labor, Communist, Socialist, or Social Democratic. In the U.S. the Democratic Party is excluded. If it were included, for consistency sake a wide array of comparable nominal left-liberal parties in the other nations would have to be included as well, rendering this measure virtually meaningless. Data were derived from Mackie and Rose (1991) as well as Electoral Studies and The European Journal of Political Research. Identification of parties was verified using Lane, McKay, and Newton (1997). 


\section{Appendix (continued)}

Union Density: Number of union members divided by the total dependent labor force (wage/salary earners plus non-retired unemployed). Data from multiple sources: Bain and Price (1980); Visser (1992); Golden, Lange, and Wallerstein (1997), as utilized in Gray and Caul (2000).

Margin of Victory: A measure of the difference between the total vote shares of the two parties that received the most votes in the election. Data collected from Mackie and Rose (1991) and updated with Electoral Studies and The European Journal of Political Research.

Number of Parties: Calculated as the number of parties with vote shares greater than five percent. Data derived from Mackie and Rose (1991) as well as Electoral Studies and The European Journal of Political Research.

Inflation: Percentage change in the CPI index for the given year in which the election takes place. Derived from OECD Economic Outlook.

Economic Growth: Percentage annual growth in gross domestic product during the election year. Derived from OECD Economic Outlook.

Electoral Competitiveness: Operationalized as classified by Shugart in unpublished data for Taagepera and Shugart (1989). The ordinal scale simultaneously measures district magnitude and proportionality of seat allocation capturing the systematic "competitiveness" of any given nation's districting system:

$1 \mathrm{M}=1$ plurality (includes any final ballot in presidential elections);

$2 \mathrm{M}=1$ two rounds majority;

$3 \mathrm{M}=1$ majority at first ballot, plurality at second;

$4 \mathrm{M}>1$ plurality;

$5 \mathrm{M}>1$ two-rounds;

$6 \mathrm{M}>1$ majority at first ballot, plurality at the second;

$7 \mathrm{M}>1$ single nontransferable vote;

$8 \mathrm{M}>1$ limited vote;

9 PR, low magnitude $(M<6)$ d'Hondt or Hagenbach-Bischoff;

$10 \mathrm{PR}$, low magnitude, Ste.-Lague;

$11 \mathrm{PR}$, low magnitude, quota and largest remainders;

12 PR, high magnitude (avg. 6 to 20), d'Hondt or Hagenbach-Bischoff;

13 PR, high magnitude, Ste.-Lague;

14 PR, high magnitude, quota and largest remainders;

15 PR, effective nationwide allocation, d'Hondt;

16 PR, effective nationwide allocation, Ste.-Lague;

17 PR, effective nationwide allocation, quota and largest remainders.

Compulsory Voting: A $(0,1)$ dummy variable that takes the value of "1" for compulsory voting laws.

Voting Holiday: A $(0,1)$ dummy variable that takes the value of " 1 " when any nation holds an election on a weekend or holiday.

Unicameralism: A $(0,1)$ dummy variable that takes the value of " 1 " where unicamerialism.

Indices of Differences in Party Profiles: Collected from Comparative Manifestos Project. Index of Left Emphases minus Index of Right Emphases. Left Emphasis is the sum of the following: Anti-Imperialism (V103); Anti-Military (105); Pro-Peace (V106); Pro-Internationalism (V107); Democracy (V202); Regulate Capitalism (V403); Economic Planning (V404); Pro-Protectionism (406); Controlled Economy (V412); 


\section{2 | Miki Caul Kittilson}

\section{Appendix (continued)}

Indices of Differences in Party Profiles (continued)

Nationalization (V413); Pro-Social Services (V504); Pro-Education (V506); ProLabor (V701). Index of Right Emphases are the sum of: Pro-Military (V104); Freedom/Human Rights (V201); Pro-Constitutionalism (V203); Effective Authority (V305); Free Enterprise (V401); Economic Incentives (V402); Anti-Protectionism (V407); Economic Orthodoxy (V414); Anti-Welfare (V505); Natural Way of Life (V601); Traditional Morality (V603); Law and Order (V605); Social Harmony (V606).

\section{NOTES}

${ }^{1}$ The height of the union-labor party relationship differs for each nation, but in general we can say the 1960 s.

${ }^{2}$ Observations for every national election in the 18 continuously democratic industrialized nations with populations over 500,000 since 1950 are included. Data on presidential and parliamentary contests are organized within a stacked pooled data set within their own panels.

${ }^{3}$ It is important to note that the Ghobarah bases turnout on the number of registered voters and not the eligible voting-age population, and still finds aggregate decline.

${ }^{4}$ The U.S. Democratic Party is excluded for consistency sake. Inclusion of the Democrats would necessitate inclusion a wide array of comparable nominal left-liberal parties in the other nations of this study, which would render the measure virtually meaningless. Therefore, the inclusion is limited to self-identified Communist, Labor, Socialist, or Social Democratic parties.

${ }^{5}$ Only in Germany, Ireland, and somewhat in New Zealand have the "labor" parties' share of votes increased since 1950. In general, for Australia, Austria, France, Germany, Japan, Switzerland, and the United Kingdom, the decline for the left has been occurring since the 1980s (Gray and Caul 2000).

${ }^{6}$ The Comparative Manifestos Project coded platforms in terms of issue concerns, following Budge et al.'s (1987) salience theory of party competition, rather than on the basis of position. While most of the categories in this index are coded on a pro- or antibasis, some are only designed to capture policy emphases. Budge (1999) uses this same index procedure to trace Left-Right images of British parties over time (see also Hofferbert 1997). Harmel et al. (1995) question the salience coding scheme, arguing that ideological position must be coded strictly in terms of positive or negative statements. It is certainly important not to conflate issue emphases with ideological position, and the results are interpreted with this in mind.

${ }^{7}$ The leading left and right parties in each country are: Swedish Social Democrats and People's Party (1952-64) Center (1968-79; 1991-1998) Moderate Unity (1979-88); Norwegian DNA (Labour) and Hoyre (Conservatives); Danish Social Democrats and Ventsre (Liberals) (1950-68; 1994-98) Conservatives (1971 and 1981-88) and Progress (1973) and Liberals (1975); Finnish Social Democrats and National Coalition; Belgian Socialists (Francophone 1978-81; 1987; 1991 and Flemish 1985; 1995) and CVP; Dutch PvdA (Labor) and KVP (Catholic People's) and CDA (1981-1994) VVD (1998); French Communist (1951-73) and Socialist (1978-97) and Gaullist (1951 and 1958-88) and 
Conservatives (1956) and Rally for the Republic 1993-1997; Italian PCI (Communists) and DC (Christian Democrats) 1963-1983 and PPI-PC (1992) and Forza Italia (19941996); German SPD (Social Democrats) and CDU (Christian Democratic Union); Austrian SPO (Socialists) and OVP (People's Party); Swiss SPS-PSS Social Democrats and FDP-PRD Radical Democrats; UK Labour and Conservatives; Irish Labour and Fianna Fail and Fine Gael after 1989; US Democrats and Republicans, Canadian NDP (Socialist) and Liberals; Australian Labour and Liberals; New Zealand Labour and National; Japan JSP Socialist (1960-1993) and Communist (1996) and LDP Liberal Democrats.

${ }^{8}$ Yet Britain, the archetype majoritarian system, witnesses no convergence. However, if analysis of the 2001 platform were available, one might expect to see a greater degree of convergence.

${ }^{9}$ The same analysis without weighting each party by its share of the votes. Hence, a small fringe party weighs equally with the largest party. The results are similar, reinforcing the pattern of convergence across the party system.

${ }^{10}$ There are two nations that produce opposing trends. Both Canada and France show convergence for the two major parties, but not when the entire system is taken into account.

${ }^{11}$ This dataset and method of measuring change in turnout was originally developed in a co-authored project, see Gray and Caul (2000).

${ }^{12}$ The true $n=286$, but after removing the first two elections as standardizing elections for each nation and each type of election within those nations, there are only 230 cases.

${ }^{13}$ The data are arranged first by nation, then by type of election, and then by year, providing a stacked series of observations for each country and each type of election over time.

${ }^{14} \mathrm{~A}$ pooled estimation of our TSCS using untransformed data (the actual levels of each variable) explains differences between countries rather than changes within countries (this estimation is provided in Table 5). Because the focus of this research is on declining turnout, the standardized measures of change represent the optimum procedure (for more detailed explanation see Gray and Caul (2000).

${ }^{15}$ While it has almost become standard practice to use the levels of variables with OLS regression and a lagged endogenous variable this procedure is not an effective measure of change (see Bartels and Brady 1993,130; Johnston and DiNardo 1997, 194; Klein 1997, 12).

${ }^{16}$ This is specific to election type. For example, in the U.S. case off-year and onyear elections are set on the same plane as they are standardized only by other off-year and on-year elections.

${ }^{17}$ This is limited to "a great deal" because after a sufficient number of elections, cross-national variation will reappear to the extent that these nations have different trajectories of decline. Country dummy variables are utilized to ensure that panel differences do not enter into the findings. Dummy variables for New Zealand, Switzerland, and the UK are statistically significant.

${ }^{18}$ Includes presidential elections. The same multivariate analysis was done with legislative elections only, and yielded similar results. The coefficients for unionization, number of parties, and GDP were all statistically significant. None of the country dummies was statistically significant.

${ }^{19}$ Even when the alternative measure of ideological dispersion of the entire party system is substituted in the equation (standard deviation of party profiles), this explanation has virtually no impact on turnout rates. 


\section{4 | Miki Caul Kittilson}

${ }^{20}$ Both the number of parties in the system and economic growth are statistically significant indicators. However, the magnitude of both of these coefficients is rather small.

\section{REFERENCES}

Almond, Gabriel, and Sidney Verba. 1963. The Civic Culture. Boston, MA: Little, Brown.

Bain, George, and Robert Price. 1980. Profiles of Union Growth. Oxford: Basil Blackwell.

Banks, Arthur. 1997. Cross-National Time Series Data Archive [electronic data file]. Binghamton, NY: Computer Solutions Unlimited.

Bartels, Larry, and Henry Brady. 1993. The State of Quantitative Political Methodology. Pp. 121-162 in The State of the Discipline II, ed. Ada W. Finifter. Washington, DC: American Political Science Association.

Beck, Nathaniel, and Jonathan Katz. 1995. What To Do (and Not to Do) with TimeSeries Cross-Section Data in Comparative Politics. American Political Science Review 89:634-647.

Budge, Ian. 1999. Party Policy and Ideology: Reverting to the1950s? In Critical Elections: British Parties and Voters in Long-Term Perspective, eds. Geoffrey Evans and Pippa Norris. London: SAGE Publications.

Budge, Ian, David Robertson, and Derek Hearl, eds. 1987. Ideology, Strategy and Party Change: Spatial Analysis of Postwar Election Programs in 19 Democracies. Cambridge: Cambridge University Press.

Budge, Ian, Hans-Dieter Klingemann, Andrea Volkens, Judith Bara, and Eric Tannenbaum. 2001. Mapping Policy Preferences. Estimates for Parties, Electors and Governments, 1945-1998. Oxford: Oxford University Press.

Burnham, Walter Dean. 1987. The Turnout Problem. Pp. 97-133 in Elections American Style, ed. James A. Reichley. Washington, DC: The Brookings Institution.

Burnham, Walter Dean. 1965. The Changing Shape of the American Political Universe. American Political Science Review 59(1):7-28.

Caul, Miki, and Mark Gray. 2002. From Platform Declarations to Policy Outcomes: Changing Party Profiles and Partisan Influence Over Policy. In Parties Without Partisans: Political Change in Advanced Industrial Democracies, eds. Russell J. Dalton and Martin P. Wattenberg. New York: Oxford University Press.

Crewe, Ivor, and David Denver, eds. 1985. Electoral Change in Western Democracies. London: Croom Helm.

Dalton, Russell J., Scott Flanagan, and Paul Beck, eds. 1984. Electoral Change in Advanced Industrial Democracies. Princeton, NJ: Princeton University Press.

Dalton, Russell J., and Martin P. Wattenberg. 2000. Parties without Partisans: Political Change in Advanced Industrial Democracies. New York: Oxford University Press.

Dittrich, Karl, and Lars Norby Johansen. 1983. Voting Turnout in Europe, 1945-78: Myths and Realities. Pp. 05-114 in Western European Party Systems, eds. Hans Daadler and Peter Mair eds. London: SAGE.

Electoral Studies. 1990-1997. National Elections. In Electoral Studies. Guildford, England: Butterworths. 
European Journal of Political Research. 1993-1997. Election Results in European Journal of Political Research. Dordecht, The Netherlands: Kluwer Academic Publishers.

Franklin, Mark N. 2002. The Dynamics of Electoral Participation. In Comparing Democracies 2: New Challenges in the Study of Elections and Voting, eds. Lawrence LeDuc, Richard G. Niemi, and Pippa Norris. London: SAGE.

Ghobarah, Hazem. 1998. The Decline in Voter Turnout Across the Advanced (Post) Industrial Democracies, 1980-1998. Paper presented at the annual meeting of the American Political Science Association Meeting, Boston.

Golden, Miriam, Peter Lange, and Michael Wallerstein. 1997. Union Centralization among Advanced Industrial Societies: An Empirical Study. Dataset available at http://shelly.sscnet.ucla.edu/data.

Gray, Mark. 1998. Institutional Explanations of Voter Turnout in Mature Industrial Democracies: If You Build It They May Not Come. Paper presented at the annual meeting of the Western Political Science Association, Los Angeles.

Gray, Mark. 2003. In the Midst of Fellows: The Context of the American Turnout Decision. Diss., University of California Irvine.

Gary, Mark, and Miki Caul. 2000. Declining Voter Turnout in Advanced Industrial Democracies, 1950 to 1997: The Effects of Declining Group Mobilization. Comparative Political Studies 33(9):1091-1122.

Griffin , L. H. McCammon, and C. Botsko. 1990. The Unmaking of a Movement? The Crisis of U.S. Trade Unions in Comparative Perspective. Pp. 169-194 in Changes in Societal Institutions, eds. M. Hallinan, D. Klein, and J. Glass. New York: Plenum.

Harmel, Robert, and Alexander Tan. 1995. Substance vs. Packaging. Paper presented at the annual meeting of the Midwest Political Science Association, Chicago.

Hofferbert, Richard. 1997. The Patterns of Party Concerns in Modern Democracies. Paper presented at the Workshop on Change in the Relationship Between Parties and Democracy, Texas A\&M University, 4-6 April.

IDEA Database. 1997. Voter Turnout from 1945 to 1997: A Global Report on Political Participation. Stockholm, Sweden: International Institute for Democracy and Electoral Assistance.

Inglehart, Ronald. 1990. Culture Shift in Advanced Industrial Society. Princeton, NJ: Princeton University Press.

Jackman, Robert. 1987. Political Institutions and Voter Turnout in Industrial Democracies. American Political Science Review 81:405-423.

Jackman, Robert, and Ross Miller. 1995. Voter Turnout in the Industrial Democracies During the 1980s. Comparative Political Studies 27:467-492.

Johnston, Jack, and John DiNardo. 1997. Econometric Methods. New York: McGrawHill.

Kirchheimer, Otto. 1966. The Transformation of the Western European Party Systems. In Political Parties and Political Development, eds. Joseph LaPalombara and Myron Weiner, eds. Princeton, NJ: Princeton University Press.

Klein, Judy. 1997. Statistical Visions in Time. Cambridge: Cambridge University Press.

Klingemann, Hans-Dieter, and Dieter Fuchs. 1995. Citizens and the State. New York: Oxford University Press.

Knutsen, Oddbjorn. 1998. Expert Judgments of the Left-Right Location of Political Parties: A Comparative Longitudinal Study. West European Politics 21:63-94.

Lane, Jan-Erik, David McKay and Kenneth Newton. 1997. Political Data Handbook OECD Countries. New York: Oxford University Press. 
Lewis-Beck, Michael. 1980. Applied Regression. London: SAGE.

Lewis-Beck, Michael, and Brad Lockerbie. 1989. Economics, Votes and Protests: Western European Cases. Comparative Political Studies 22:155-77.

Lijphart, Arend. 1994. Electoral Systems and Party Systems: A Study of Twenty-Seven Democracies, 1945-1990. New York: Oxford University Press.

Lijphart, Arend. 1997. Unequal Participation: Democracies' Unresolved Dilemma. American Political Science Review 91:1-14.

Lipset, Seymour Martin. 1960. Political Man: The Social Basis of Politics. New York: Doubleday.

Lipset, Seymour Martin, and Stein Rokkan, eds. 1967. Party Systems and Voter Alignments: Cross-National Perspectives. New York: The Free Press.

Mackie, Thomas, and Richard Rose. 1991. The International Almanac of Electoral History. Washington, DC: CQ Press.

Mair, Peter. 1995. Political Parties, Popular Legitimacy, and Public Privilege. West European Politics 18:40-57.

OECD. 1982-1997. OECD Economic Outlook: Historical Statistics. Paris: Organization of Economic Cooperation and Development.

Pacek, Alexander, and Benjamin Radcliff. 1995. Turnout and the Vote for Left-of-Centre Parties: A Cross-National Analysis. British Journal of Political Science 25:137143.

Pesonen, Pertti. 1 999. Politics in Finland. In Comparative Governance, ed. W. Philipps Shively. New York: McGraw-Hill.

Powell, G. Bingham. 1986. American Turnout in Comparative Perspective. American Political Science Review 80:17-43.

Powell, G. Bingham. 1980. Voting Turnout in Thirty Democracies: Partisan, Legal, and Socio-Economic Influences. In Electoral Participation: A Comparative Analysis, ed. Richard Rose. Beverly Hills, CA: SAGE.

Radcliff, Benjamin. 1992. The Welfare State Turnout, and the Economy: A Comparative Analysis. American Political Science Review 86:444-454.

Radcliff, Benjamin. 1996. Turnout and the Economy. Comparative Political Studies 29:718-723.

Radcliff, Benjamin, and Patricia Davis. 2000. Labor Organization and Electoral Participation in Industrial Democracies. American Journal of Political Science 44:132141.

Rosenstone, Steven, and Mark Hansen. 1993. Mobilization, Participation, and Democracy in America. New York: Macmillian.

Rubin, Alissa. 1998. This Time, Unions Mobilized the Troops. The Los Angeles Times, November, p. A5.

Stimson, James A. 1985. Regression in Space and Time. American Journal of Political Science 29:914-947.

Taagepera, Rein, and Matthew Shugart. 1989. Seats and Votes. New Haven, CT: Yale University Press.

Taylor, Andrew J. 1993. Trade Unions and the Politics of Social Democratic Renewal. West European Politics 16:133-156.

Teixeira, Ruy. 1992. The Disappearing American Voter. Washington, DC: The Brookings Institution.

Thomas, John Clayton. 1975. The Decline of Ideology in Western Political Parties. Beverly Hills, CA: SAGE. 
Thomas, John Clayton. 1979. The Changing Nature of Partisan Divisions in the West: Trends in Domestic Policy Orientations in Ten Party Systems. European Journal of Political Research 7:397-413.

Topf, Richard. 1995. Electoral Participation. Pp. 28-51 in Citizens and the State, eds. Hans-Dieter Klingemann and Dieter Fuchs. New York: Oxford University Press.

Uhlaner, Carole. 1989. Rational Turnout: The Neglected Role of Groups. American Journal of Political Science 33:390-422.

United Nations. 1950-1993. United Nations Demographic Yearbooks. New York: United Nations.

Verba, Sidney, and Norman Nie. 1972. Participation in America. New York: Harper \& Row.

Verba, Sidney, Norman Nie, and Jae-on Kim. 1978. Participation and Political Equality. Chicago: University of Chicago Press.

Verba, Sidney, Kay Schlozman, and Henry Brady. 1995. Voice and Equality. Cambridge, MA: Harvard University Press.

Visser, Jelle. 1992. Trade Union Membership Database. Amsterdam, The Netherlands: Unpublished dataset.

Vowles, Jack, et al. 1995. Towards Consensus. Auckland, New Zealand: Auckland University Press.

Wagschal, Uwe. 1998. Parties, Party Systems, and Policy Effects. In Comparing Party System Change, Paul Pennings and Jan-Erik Lane. London: Routledge.

Wallerstein, Michael. 1989. Union Organization in Advanced Industrial Democracies. American Political Science Review 83:481-501. 
